\title{
Monetyzacja efektów społecznych ${ }^{1}$
}

\section{Jakub Głowacki*}

\begin{abstract}
Streszczenie: Jedną z kluczowych barier rozwoju sektora ekonomii społecznej w Polsce jest brak powszechnej wiedzy i umiejętności w zakresie skutecznego i systematycznego mierzenia dokonań. Jest to o tyle istotne, że - mimo zwiększającej się świadomości społecznej w zakresie korzyści generowanych przez ten sektor - wciąż artykułowane są zastrzeżenia dotyczące racjonalności wspierania przedsięwzięć społecznych. Sposobem na wymierną i skuteczną prezentację efektów działalności społecznej jest monetyzacja tych efektów, czyli nadanie im wartości pieniężnej. W niniejszym artykule dokonano przeglądu literatury związanej z wyceną dóbr nierynkowych, wypracowanych w obszarze ekologii oraz zasygnalizowano potencjalne możliwości adaptacji tego typu metod w obszarze ekonomii społecznej. Wnioski te mogą być wykorzystane do prowadzenia dalszych badań empirycznych, a także do budowy nowych metod i narzędzi oceny oddziaływania społecznego.

Słowa kluczowe: oddziaływanie społeczne, monetyzacja, metoda kosztów podróży, metoda cen hedonicznych, metoda wyceny warunkowej, metoda transferu korzyści.
\end{abstract}

\section{Wprowadzenie}

Tematyka pomiaru wpływu społecznego (ang. social impact) jest jednym z ważniejszych wyzwań stojących obecnie przed sektorem ekonomii społecznej. Od momentu wejścia Polski w struktury Unii Europejskiej w 2004 r. nastąpił znaczący wzrost wiedzy i doświadczenia instytucji w zakresie skutecznego wdrażania przedsięwzięć o charakterze społecznym [por. Pacut, 2015]. Wciąż jednak brakuje elementarnej wiedzy na temat metod oceny tego typu działań, co stanowi silną barierę rozwojową dla całego sektora.

Z zagadnieniem mierzenia wpływu społecznego jest związany mocno proces tzw. monetyzacji² efektów społecznych, czyli nada-

\footnotetext{
Publikacja powstała w ramach projektu, który został sfinansowany ze środków Narodowego Centrum Nauki przyznanych na podstawie decyzji numer DEC-2011/03/N/HS4/01388.

Monetyzacja to w praktyce pojęcie z dziedziny finansów oznaczające zamianę aktywów rzeczowych lub finansowych na pieniądze. Potocznie - przekształcanie czegoś w pieniądz. Pojęcie kojarzone jest także z polityką finansową państwa: monetyzacja deficytu oznacza sprzedaż obligacji lub bonów skarbowych w celu pozyskania środków pieniężnych na finansowanie deficytu budżetowego. Pojęcie monetyzacji
}

wania wartości pieniężnej nierynkowym towarom i usługom wytworzonym w ramach przedsięwzięć społecznych. W tym obszarze dziedziną przynoszącą wiele wartościowych rozwiązań jest szeroko rozumiana ochrona środowiska. Metody, dzięki którym istnieje możliwość przydzielenia wartości pieniężnej dla dóbr i usług nierynkowych, są stosowane także w zarządzaniu nieruchomościami [Tomczyk, Widłak, 2010], służbie zdrowia [Kolasa, 2012] czy wreszcie w ekonomii.

Jak wskazuje Żylicz [2013, s. 8], techniki wyceny dóbr nierynkowych można podzielić na dwa rodzaje: metody pośrednie i bezpośrednie. Te pierwsze bazują na obliczeniach wartości ekonomicznych poprzez badanie

może też odnosić się do kreacji (emisji) pieniądza przez bank centralny bez pokrycia (tzw. pusty pieniądz). W niniejszym artykule to pojęcie będzie odnoszone do procesu nadawania wartości pieniężnej dobrom i usługom nierynkowym.

\footnotetext{
* Jakub Głowacki

Katedra Gospodarki Publicznej

Uniwersytet Ekonomiczny w Krakowie

ul. Rakowicka 16, 31-510 Kraków

e-mail: jakub.glowacki@uek.krakow.pl
} 
tzw. rynków zastępczych (surogatowych), na których sprzedawane i kupowane są dobra komplementarne w stosunku do tego, które jest poddawane wycenie. Metody bezpośrednie odnoszą się do hipotetycznego rynku, na którym dane dobro mogłoby być przedmiotem transakcji. Metody pośrednie z reguły są uważane za bardziej wiarygodne, gdyż opie- rają się na preferencjach ujawnionych (ang. revealed preference). W przypadku metod bezpośrednich wycena jest oparta najczęściej o niezobowiązującą deklarację ankietowanego. Udoskonalanie w ostatnich latach metod bezpośrednich sprawiło, że stały się one bardziej obiektywne.

\section{Schemat 1. Klasyfikacja najważniejszych metod monetyzacji}

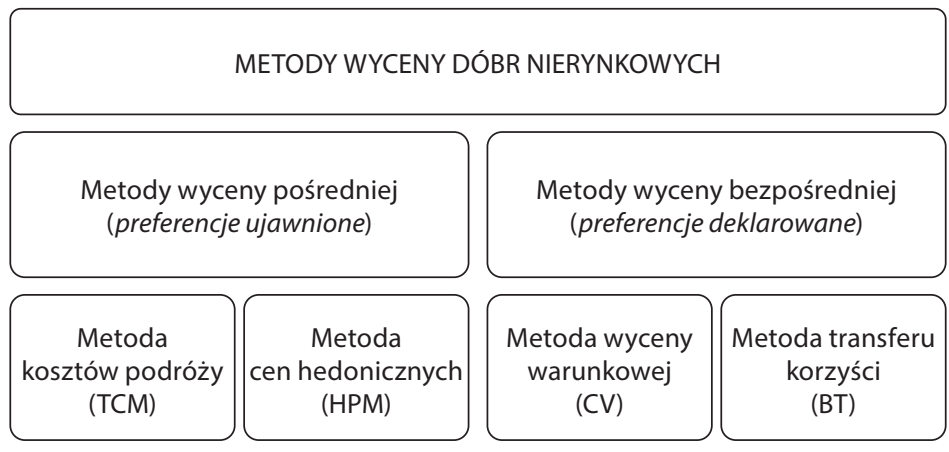

Źródło: opracowanie własne.

Niniejszy artykuł ma charakter analizy teoretycznej, która z jednej strony jest dalszym ciągiem rozważań nad wartością w ekonomii społecznej [por. Głowacki, 2015], a z drugiej strony może być wstępem do przeprowadzenia badań empirycznych. Poniżej przybliżono najważniejsze sposoby wyceny dóbr nierynkowych oraz przedstawiono ich wady oraz zalety. W końcowej części artykułu zasygnalizowano natomiast potencjalne możliwości adaptacji tego typu metod w obszarze ekonomii społecznej. Wnioski te mogą być wykorzystane nie tylko do testowania konkretnej metody wyceny dóbr nierynkowych w sektorze ekonomii społecznej (a takich badań na świecie jest niewiele), ale również do budowy nowych metod i narzędzi oceny oddziaływania społecznego.

\section{Metoda kosztów podróży}

Metoda kosztów podróży (ang. travel cost method - TCM) była jednym z pierwszych sposobów, za pomocą którego nadano wartość pieniężną dobru nierynkowemu. Swój początek TCM miała w obszarze turystyki, gdzie potrzeba określenia pieniężnego ekwiwalentu określonej atrakcji miała niebagatelne znaczenie dla przedsiębiorców działających w tym obszarze, samorządów czy innych podmiotów, których decyzje zależały w dużej mierze od czynnika pieniężnego. Pierwszym badaczem, który podjął się wyzwania obliczenia wartości na pozór niemożliwej do wyceny, był Harald Hotelling [por. Hotelling, 1949]. W czasach, gdy rząd Stanów Zjednoczonych postanowił w ramach cięć budżetowych zmniejszyć środki na utrzymanie parków narodowych, Hotelling przeprowadził obliczenia, które udowodniły, że wartość parków uwzględniająca satysfakcję setek tysięcy odwiedzających jest wielokrotnie wyższa niż wartość dotacji. 
Tym samym Hotelling swoją pracą naukową zapobiegł prawdopodobnemu obniżeniu jakości przyrodniczej parków w USA. Ta historia stanowiła podwalinę pod rozwój kolejnych metod wyceny wartości nierynkowych. Do rozwoju metody TCM przyczynili się później w dużej mierze Clawson i Knetsch [1966].

Sposób wyceny w TCM opiera się na założeniu, że ludzie są gotowi ponieść określony wysiłek, aby dokonać konsumpcji dobra nierynkowego. Relatywnie prostą miarą owego wysiłku może być wartość nakładów poniesionych na podróż, aby to dobro skonsumować. Klasyczne podejście do TCM bazuje na założeniu, że koszty dojazdu do atrakcji składają się, po pierwsze, z wynagrodzenia za czas poświęcony na podróż, a po drugie, z kosztów samego transportu (bilet na autobus/pociąg, paliwo, amortyzacja samochodu itp.). Badania Browna i Mendelsohna [Brown, Mendelsohn, 1984] przeprowadzone na grupie amerykańskich wędkarzy w latach 80. XX w. wskazują, że wartość czasu poświęconego na podróż stanowi ok. 30\% standardowego wynagrodzenia za pracę danej osoby, a oszacowany koszt przebycia jednej mili wyniósł wówczas ok. 10 centów.

W najbardziej ogólnej postaci obliczenie wartości dobra lub usługi za pomocą TCM jest oparte o następującą funkcję [Bateman, 1993, s. 4]:

$$
V=f(C, X)
$$

gdzie: $V$ oznacza popularność danego miejsca, $C$ - koszt wizyt, a $X$ - inne socjoekonomiczne czynniki, które w znaczący sposób określają $V$.

Metoda kosztów podróży posługuje się zaawansowanymi technikami matematycznymi i statystycznymi. Zebrany materiał empiryczny może być interpretowany na różne sposoby, zależnie od przyjmowanych założeń dotyczących rozkładów statystycznych. Randall [1994] przedstawia jednak ograniczenia tej metody:
1. Turyści bardzo często posiadają zróżnicowane wyposażenie, którego używają w trakcie podróży i wypoczynku. To powoduje, że wartość nakładów inwestycyjnych poniesionych przez turystę w celu osiągnięcia satysfakcji z wyjazdu zazwyczaj mocno się różni pomiędzy turystami.

2. TCM w najprostszym wydaniu zakłada, że osoby decydujące się na wyjazd rekreacyjny zmierzają do jednego celu. Często bywa jednak tak, że podróż wiąże się z odwiedzeniem kilku atrakcji. Jeżeli tak jest, wartość określona za pomocą TCM jest zawyżona. Natomiast rozdzielenie kilku składowych jest trudnym zadaniem.

3. Metoda kosztów podróży nie uwzględnia różnic w kosztach noclegów i utrzymania turysty. Często te składowe są mocno uznaniowe.

4. Istnieje wiele empirycznych dowodów [por. Rosenthal, 1987], że wykorzystywanie rynków zastępczych do szacowania wartości dobra nierynkowego za pomocą TCM wpływa niekorzystnie na uzyskane wyniki.

5. Koszt alternatywny czasu spędzonego w podróży powinien być zaliczony do jej kosztów.

Mimo swoich niedoskonałości, TCM jest współcześnie wciąż wykorzystywana w praktyce. Jednym ze znanych przykładów są badania przeprowadzone przez zespół Roberta Costanzy [Costanza et al., 1997], który podjął próbę wyceny wartości wszystkich ekosystemów świata. Badacze ci zidentyfikowali 18 typowych ekosystemów, takich jak np.: las borealny, łąka, teren podmokły, oraz 17 kluczowych korzyści z tych ekosystemów, takich jak: regulacja klimatu, zapylanie czy rekreacja. Wartości zebrane dla poszczególnych ekosystemów pomnożone przez ich obszary dały całkowitą wartość usług dostarczanych przez ekosystemy świata. Wartość uzyskana w rezultacie tego badania wyniosła 33 biliony USD (dla 1994 r.), czyli więcej, niż ówczesny wolumen światowego PKB, co wzbudziło sporo kontrowersji. 
W Polsce metoda kosztów podróży była zastosowana m.in. przez Warszawski Ośrodek Ekonomii Ekologicznej [Bartczak et al., 2005]. W toku badań oszacowano, że jednorazowa wizyta $\mathrm{w}$ polskim lesie ma wartość ok. 11-15 zł. Przeliczając tę wartość na jednostkę powierzchni i częstotliwość odwiedzin, stwierdzono, że 1 hektar lasu przynosi korzyści rekreacyjne o wartości co najmniej 1700 zł rocznie. Co ciekawe, jest to wartość przekraczająca znacznie średnią wartość drzewa pozyskiwaną z tego obszaru. Trzeba jednak zauważyć, że tak oszacowana kwota nie uwzględniała wielu dodatkowych korzyści wynikających z istnienia lasu, np. redukcji ilości dwutlenku węgla w atmosferze, produkcji tlenu czy możliwości zbierania owoców runa leśnego.

\section{Metoda cen hedonicznych}

Innym przykładem metod pośrednich jest metoda cen hedonicznych (ang. hedonic price method - HPM). W najprostszym ujęciu HPM bazuje na szacowaniu wartości dóbr nierynkowych poprzez porównywanie cen towarów na rynkach konwencjonalnych ${ }^{3}$. Przykładem może być czyste powietrze. Jego wartość jest trudna do oszacowania, ale można podjąć się próby określenia różnicy pomiędzy wartością domu znajdującego się w czystym środowisku a identycznym domem, ale w zanieczyszczonej okolicy. Ta różnica będzie oznaczała wartość czystego powietrza, którą wycenił rynek nieruchomości. Prawdopodobieństwo znalezienia dwóch takich domów jest oczywiście minimalne, jednak w praktyce metoda cen hedonicznych jest oparta o ekonometryczną analizę dużej liczby transakcji rynkowych, podczas których analizowane są korelacje

\footnotetext{
Na kwestię trudności związanych z ekonomicznym pomiarem użyteczności nabywanych dóbr zwrócił uwagę Schumpeter [1995], wskazując, że potęp techniczny zwiększa ich wartość użytkową, choć ceny z reguły zmniejszają się (patrz: przykład komputerów). Zwięzłe omówienie teorii Schumpetera przedstawia m.in. Geodecki [2014].
}

pomiędzy określonymi atrybutami pewnych dóbr a ich ceną. Opisywana metoda została zastosowana po raz pierwszy w praktyce do wyjaśnienia systematycznych różnic w rynkowych cenach win [por. Oczkowski, 1994]. Postawiono hipotezę, iż na wartość wina ma wpływ wiele czynników, takich jak smak, zapach, kolor itd., które same nie mają szansy być przedmiotem wymiany rynkowej. Z takiej szansy korzysta jednak wino, stanowiące wiązkę wspomnianych czynników. Starannie dobierając i analizując próbę statystyczną można obliczyć, ile konsumenci są gotowi zapłacić za poszczególne czynniki.

Krytyka metody cen hedonicznych opiera się na kilku argumentach. Jeden $z$ nich jest taki, że metoda ta uwzględnia korzyści ekonomiczne jedynie wówczas, gdy na rynku dostrzegana jest wartość tych atrybutów, które zamierzamy mierzyć. Gdy tak nie jest, wartość czystego powietrza w otoczeniu domu z wyżej przytoczonego przykładu nie będzie odzwierciedlona w wartości nieruchomości. Ponadto, metoda cen hedonicznych w wersji użytkowej (nie teoretycznej) wymaga wysokiego stopnia wiedzy statystycznej, a jej wyniki w dużym stopniu zależą od specyfiki wypracowanego modelu. Metoda wymaga także dużej ilości danych, aby analiza była wiarygodna, a czas i koszty przeprowadzenia obliczeń w dużej mierze zależą właśnie od dostępności tych danych.

\section{Metoda wyceny warunkowej}

Metoda wyceny warunkowej (ang. Contingent Valuation Method - CVM) jest to sposób wyceny wartości dóbr, które najczęściej nie są przedmiotem obrotu rynkowego i w związku z tym nie mają ceny określonej przez mechanizmy rynkowe. Dobra wyceniane w ten sposób to najczęściej dobra publiczne, takie jak jakość wody w rzece czy bezpieczeństwo publiczne. Początkowo metoda wykorzystywana była do wyceny efektów realizacji projektów w obszarze turystyki [Carson, 2011, 
s. 4]. Za jej prekursora uznaje się Roberta Davisa, który zastosował metodę w praktyce i w 1963 r. opublikował swoje wyniki w dysertacji pt. The value of outdoor recreation: an economic study of the Maine woods.

Istnieją dwa podejścia do metody wyceny warunkowej. Pierwsze z nich opiera się na tzw. skłonności do zapłaty (ang. willigness to pay - WTP) i w praktyce oznacza badanie ankietowe, w którym respondenci są pytani o to, jaką wartość byliby w stanie zapłacić, aby uzyskać dostęp do danego dobra. W tym podejściu celem badania jest określenie maksymalnej kwoty, jaką ktoś jest w stanie zapłacić. Drugie podejście jako podstawę do przeprowadzenia wyceny wykorzystuje pytanie o skłonność do porzucenia pewnego dobra lub do zaakceptowania niekorzystnego zjawiska (np. zanieczyszczenia) za określoną cenę (ang. willingness to accept - WTA) [Alberini et al., 2000, s. 7]. W tym przypadku określa się minimalną kwotę potrzebną do akceptacji danej niedogodności. Oba podejścia można zapisać w postaci następujących funkcji [Bateman, Willis, 1999, s. 101]:

$$
\begin{aligned}
& W T P=E\left(P, q^{0}, Q, U^{0}\right)-E\left(P, q^{1}, Q, U^{0}\right) \\
& W T A=E\left(P, q^{1}, Q, U^{1}\right)-E\left(P, q^{0}, Q, U^{1}\right)
\end{aligned}
$$

gdzie: $E$ - funkcja wydatków, $P$ - wektor cen dla dóbr rynkowych, $q$ - ilość konsumowanych dóbr nierynkowych, Q - wektor innych dóbr nierynkowych, $U^{i}$ - użyteczność indywidualna podczas konsumpcji $q^{i}$.

Mimo tego, że metoda wyceny warunkowej była szeroko stosowana w ostatnich latach, pojawiają się kontrowersje co do tego, czy odpowiednio szacuje skłonność do płacenia za dobra i usługi nierynkowe [Bartczak et al., 2011, s. 62]. Wycena za pomocą metody CVM nosi nazwę warunkowej, gdyż wymaga zastosowania hipotetycznego scenariusza, w którym wyceniane dobro podlega pewnej zmianie, na którą to zmianę respondenci mogą w określony sposób zareagować (zgodnie ze swoimi preferencjami). Bazowanie jedynie na odpowiedziach respondentów jest z jednej strony największą słabością tej metody, ale jednocześnie także jej największą zaletą. Pozwala ona bowiem na bardzo dużą elastyczność i wycenę dóbr i usług, dla których rynki nie istnieją, i których inaczej nie sposób wycenić. Badania przeprowadzane tymi metodami są stosunkowo kosztowne ze względu na skomplikowany, długi i trudny proces wyboru i przygotowania odpowiedniego scenariusza. Kolejnym ograniczeniem jest niezdolność respondentów do dokonywania racjonalnych wyborów w sytuacjach, w których nie mają doświadczenia. Następnym elementem problemowym jest takie przeprowadzenie badania, aby zdobyć rzetelne odpowiedzi, które będą podstawą do przeprowadzenia obliczeń, nie zaś skłonienie respondentów jedynie do wyrażenia ich opinii na temat dobra czy określonego scenariusza. Nierzadkim problemem jest także niezamierzone łączenie przez respondentów wycenianych dóbr z innymi, co w praktyce powoduje określanie gotowości do zapłaty za zupełnie inny koszyk, niż przewidywany przez badaczy. Wreszcie istnieje ryzyko, że w nieodpowiednio skonstruowanym scenariuszu respondenci, z uwagi na hipotetyczność pytań i odpowiedzi, mogą zachowywać się strategicznie, wykazując skłonność do jazdy na gapę (ang. free ride effect) lub zawyżania podawanych przez siebie kwot.

Pierwsze doświadczenia z wykorzystaniem ankiet w celu badania preferencji konsumentów sięgają lat 40. XX w. Miały one na celu przewidywanie zakupów konsumentów w badaniach prowadzonych przez Rezerwę Federalną USA. Prekursorami tego typu badań dotyczących dóbr środowiskowych byli Bowen [1943] oraz Ciriacy-Wantrup [1947]. Z uwagi na hipotetyczność pytań i problemy z konstrukcją scenariusza, które dziś już uważa się za przezwyciężone, metoda ta przez kolejnych 30 lat była traktowana nieufnie [Hanemann, 1994]. Stopniowo jednak zaczęła zyskiwać popularność oraz akceptację ekonomistów. Sytuacja zmieniła się wraz z katastrofą ame- 
rykańskiego tankowca Exxon Valdez w 1989 r. u wybrzeży Alaski [Loomis, 2001]. Choć wyciek ropy miał spektakularne rozmiary, $w$ okolicy niemal nie było osób, które byłyby osobiście poszkodowane (np. ich własność byłaby zanieczyszczona). Wobec oczywistej szkody dla środowiska, amerykańskie ekologiczne organizacje pozarządowe wystąpiły do sądu o odszkodowanie na rzecz zniszczonej przyrody. W oparciu o metodę wyceny warunkowej określano straty na kwotę od 3 do 15 mld USD. W odpowiedzi koncern naftowy rozpoczął finansowanie badań mających za cel zdyskredytowanie metody, a co za tym idzie odrzucenie roszczenia, jako obliczonego nienaukowymi metodami. Doprowadziło to do ożywionej publicznej i naukowej debaty, która w efekcie przyczyniła się do udoskonalenia założeń CVM [Boyle, 2004].

W Polsce doświadczenia z wykorzystaniem tej metody są nieliczne. Pierwsze w Polsce (i jedno z pierwszych na świecie) zastosowań skodyfikowanych przez Arrowa [por. Arrow et al., 1993] zasad konstrukcji badań CVM dotyczyło wyceny szkód spowodowanych eutrofizacją Morza Bałtyckiego. Badanie przeprowadzono w 1994 r. Gotowość do zapłacenia za przywrócenie Bałtyku do życia przez dorosłego Polaka oszacowana została wówczas na 169 zł/rok [Markowska, Żylicz, 1999].

\section{Metoda transferu korzyści}

Metoda transferu korzyści (ang. benefit transfer - BT) polega na wykorzystaniu wyników z wcześniej przeprowadzonych badań (bądź z opinii ekspertów) i dopasowaniu ich do warunków, dla których obecnie poszukuje się wartości. Transferowanie wartości odbywa się nie tylko dla korzyści, lecz również dla kosztów, dlatego niekiedy można spotkać się z ogólniejszą nazwą tej metody - "transfer wartości" (ang. value transfer). Do wyceny zzastosowaniem metody BT wykorzystuje się bazy danych zawierające wyniki uprzednio przeprowadzanych wycen. Badań dotyczących wyceny dóbr środowiskowych metodami opierającymi się na preferencjach ujawnionych w Europie Zachodniej oraz Ameryce Północnej przeprowadzono dziesiątki tysięcy. Część z wyników tych badań zebranych jest w elektronicznych bazach danych, takich jak np. EVRI (Environmental Valuation Reference Inventory), ENVALUE (Environmental Valuation Database) czy ValueBase (Valuation Study Database for Environmental Change in Sweden). Metoda transferu korzyści jest znacznie prostsza od pozostałych metod wyceny. Charakteryzuje się także znacząco niższym kosztem i czasem przeprowadzenia badań, niż ma to miejsce w przypadku badań "pierwotnych" (tzn. badań odwołujących się do preferencji ujawnionych bądź zadeklarowanych). Jednak otrzymywane tą metodą wyniki obarczone są wyższą niepewnością. Dzieje się tak dlatego, że do niepewności wyników badań pierwotnych dodajemy niepewność związaną z transferowaniem wyników wyceny.

Największym ograniczeniem opisywanej metody jest tzw. błąd transferu, który wynika z tego, że wykorzystując metodę, na pewno nie otrzyma się dokładniejszych oszacowań niż w przypadku badań pierwotnych. Aby sprawdzić, o ile zastosowanie transferu korzyści zwiększa niedokładność wyników, przeprowadza się tzw. transfery eksperymentalne. W zależności od wielkości błędu dopasowania, dokładność wyników BT można podzielić na kilka grup: do $20 \%$ dopasowanie wartości jest bardzo dobre, przy błędzie do 50\% dopasowanie jest dobre, natomiast powyżej 100\% dopasowanie uważa się za słabe lub bardzo słabe.

\section{Wnioski z analizy}

Potencjał wykorzystania metod wyceny środowiskowej w procesie monetyzacji efektów społecznych jest duży. W przypadku metody kosztów podróży istnieje możliwość zbierania informacji od beneficjentów okre- 
ślonych usług społecznych, którzy decydują się na pokonanie pewnych odległości, żeby uzyskać świadczenia. Przykładem takich usług mogą być bezpłatne szkolenia oraz studia podyplomowe, usługi poradnictwa prawnego, dożywianie i noclegownie osób bezdomnych itp. Zatem metoda kosztów podróży może być użyteczna w procesie wyceny efektów, jakie przynosi działalność polegająca na świadczeniu usług społecznych, z których korzystają beneficjenci reprezentujący różne miejsca zamieszkania/stałego pobytu.

Metoda cen hedonicznych może być stosowana jedynie w ograniczonym zakresie. Można jednak podjąć niełatwe wyzwanie porównania wyników finansowych przedsiębiorstwa społecznego z analogicznych podmiotem komercyjnym (działającym w takim samym sektorze, zatrudniającym taką samą liczbę osób itp.). Różnica w zysku osiąganym przez te dwa podmioty może być wskazówką dla określenia społecznej wartości dodanej przedsiębiorstwa społecznego [por. Głowacki, 2015]. Oczywiście, podobnie jak w założeniach dla metody cen hedonicznych, tutaj również potrzebna byłaby analiza bazująca na dużej ilości danych, co w przypadku zróżnicowania podmiotów i ograniczonej wielkości sektora społecznego w Polsce jest utrudnione.

Największe możliwości wiążą się z wykorzystaniem metody wyceny warunkowej, która

\section{Literatura}

Alberini A., Cooper J. (2000). Applications of the contingent valuation method in developing countries. A survey. Roma: FAO Food and Agriculture Organization of the United Nations.

Arrow K.J., Solow R., Portney P., Learmer E., Radner R. (1993). „Report of the NOAA Panel on Contingent Valuation", Federal Register, nr 58(10), s. 46024614.

Bartczak A., Buszko-Briggs M., Żylicz T. (2005). Wycena wartości lasów w Polsce. Maszynopis niepublikowany.

Bartczak A., Czajkowski M., Kopańska A., Markowska A., Żylicz T. (2011). Wartości nierynkowych korzyści z lasów. Metody wyceny oraz zastosowanie z uwagi na swą elastyczność może służyć do wyceny właściwie wszystkich efektów przedsięwzięć społecznych. Szczególne znaczenie może mieć ta metoda dla przedsiębiorstw społecznych typu WISE, których pozytywne efekty widoczne są na rynku pracy oraz w realnej polityce społecznej państwa [por. Frączek, Laurisz, 2012]. Trzeba jednak mieć na uwadze fakt, że wycena warunkowa ma też swoje ograniczenia i wynik badania może być obarczony błędami.

W przypadku metody transferu korzyści model zagospodarowania tego narzędzia w obszarze ekonomii społecznej mógłby polegać na stworzeniu bazy danych, która zawierałaby uśrednione wyniki przeprowadzanych wycen typowych efektów społecznych (np. oszczędności dla sektora publicznego wynikające z podjęcia pracy przez osobę długotrwale bezrobotną lub niepełnosprawną, korzyści dla społeczeństwa związane z większym poczuciem bezpieczeństwa). Na podstawie zebranych danych źródłowych istniałaby możliwość uproszczonej wyceny efektów społecznych osiąganych przez niewielkie podmioty ekonomii społecznej, które w Polsce nie dysponują jeszcze odpowiednimi zasobami do obliczania, przybliżonej nawet, wartości wygenerowanych do otoczenia efektów społecznych.

wyników w analizach ekonomicznych. Warszawa: POLFOREX, http://www.polforex.wne.uw.edu.pl/ docs/przewodnik_v3_final.pdf (dostęp: 19.12.2018).

Bateman I. (1993). Evaluation of the environment: a survey of revealed preference techniques. Working Paper No. 93-06. London: Centre for Social and Economic Research on the Global Environment.

Bateman I., Willis K.G. (1999). Valuing Environmental Preferences: Theory and Practice of the Contingent Valuation Method in the US, EU and developing Countries. Oxford: Oxford University Press.

Bowen H.R. (1943). "The interpretation of voting in the allocation of economic resources", Quarterly Journal of Economics, nr 58, s. 27-48.

Boyle K.J. (2004). "Contingent valuation in practice", w: P. A. Champ, K. J. Boyle, T. C. Brown (red.), A primer 
on nonmarket valuation. Dordrecht: Kluwer Academic Publishers.

Brown G., Mendelsohn R. (1984). "The Hedonic Travel Cost Method", The Review of Economics and Statistics, Vol. 66, No. 3, s. 427-433.

Carson R.T. (2011). Contingent Valuation. A Comprehensive Bibliography and History. Cheltenham: Edward Elgar Publishing Inc.

Ciriacy-Wantrup S.V. (1947). "Capital returns from soil-conservation practices". Journal of Farm Economics, nr 29, s. 1181-1196.

Clawson M, Knetsch J. (1966). Economics of Outdoor Recreation. Baltimore: John Hopkins University Press.

Costanza R., d'Arge R., de Groot R., Farber S. (1997). „The value of the world's ecosystem services and natural capital", Nature, nr 387, s. 253-260.

Frączek M., Laurisz N. (2012). „Ekonomia społeczna a rynek pracy", w: M. Frączek, S. Mazur, J. Hausner (red.), Wokół ekonomii społecznej (s. 157-176). Kraków: MSAP UEK.

Geodecki T. (2014). „Innowacje a wzrost gospodarczy", w: T. Geodecki, Ł. Mamica (red.), Polityka innowacyjna. Warszawa: Polskie Wydawnictwo Ekonomiczne.

Głowacki J. (2015). „Wartość w ekonomii społecznej”, Ekonomia Społeczna, nr 2, s. 60-68.

Hanemann W.M. (1994). "Valuing the environment through contingent valuation", The Journal of Economic Perspectives, nr 4, s. 19-43.

Hotelling H. (1949). An Economic Study of The Monetary Evaluation of Recreation In the National Parks. Washington: Letter.
Kolasa K. (2012). Optymalna alokacja zasobów w ochronie zdrowia. Warszawa: Wolters Kluwer.

Loomis J. (2001). "Contingent valuation methodology and the us institutional framework", w: I. J. Bateman, K.G. Willis (red.), Valuing environmental preferences. New York: Oxford University Press.

Markowska A., Żylicz T. (1999). "Costing an international public good: The case of the Baltic Sea", Ecological Economics, nr 30, s. 301-316.

Oczkowski E. (1994). „A Hedonic Price Function for Australian Premium Table Wine", Australian Journal of Agricultural Economics, nr 38/1, s. 93-110.

Pacut A. (2015). „Rozwój przedsiębiorczości społecznej - istota i kierunki analizy", Ekonomia Społeczna, nr 1, s. 7-20

Randall A. (1994). "A Difficulty with the Travel Cost Method", Land Economics, nr 70/1, s. 88-96.

Rosenthal D.H. (1987). "The Necessity for Substitute Prices in Recreation Demand Analyses", American Journal of Agricultural Economics, nr 69, s. 828-837.

Schumpeter J.A. (1995). Kapitalizm, socjalizm, demokracja. Warszawa: Wydawnictwo Naukowe PWN. Tomczyk E., Widłak M. (2010). „Konstrukcja i własności hedonicznego indeksu cen mieszkań dla Warszawy", Bank i Kredyt, nr 41/1, s. 99-128.

Żylicz T. (2013). Wycena usług ekosystemów leśnych, referat przedstawiony na konferencji pt. "Lasy jako czynnik rozwoju cywilizacji: współczesna i przyszła wartość lasów", 15 października.

\section{Monetization of social effects}

Summary: One of the key barriers to the development of the social economy sector in Poland is the lack of common knowledge and skills in the effective and systematic measurement of achievements. This is important because despite the growing public awareness of the benefits generated by this sector, there are still some reservations about the rationality of supporting social enterprises. The way to measurable and effective presentation of the effects of social activities is to monetise these effects, that is, to give them a monetary value. This article reviews literature related to the valuation of non-market goods developed in the area of ecology and indicates the potential for adaptation of this type of methods in the area of social economy. These conclusions can be used to conduct further empirical research as well as to build new methods and tools for social impact assessment.

Keywords: social impact, monetization, travel cost method, hedonic pricing method, conditional valuation method, benefit transfer method.

\section{Prawa autorskie i licencja / Copyright and License}

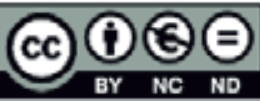

Artykuł opublikowano na licencji Creative Commons

Uznanie autorstwa - Użycie niekomercyjne - Bez utworów zależnych 3.0 Polska http://creativecommons.org/licenses/by-nc-nd/3.0/pl/

This article is published under the terms of the Creative Commons Attribution - NonCommercial - NoDerivs (CC BY-NCND 3.0) License http://creativecommons.org/licenses/by-nc-nd/3.0/ 